\title{
The interaction between housing prices and housing credit: evidence from a country with rapid credit accumulation
}

\author{
Juan Carlos Cuestas \\ Department of Economics and Iei, Jaume I University, Castellon, Spain; \\ Department of Economics and Finance, Tallinn University of Technology, \\ Tallinn, Estonia and \\ Eesti Pank, Research Unit, Tallinn, Estonia, and \\ Merike Kukk \\ Department of Economics and Finance, Tallinn University of Technology, \\ Tallinn, Estonia and \\ Eesti Pank, Research Unit, Tallinn, Estonia
}

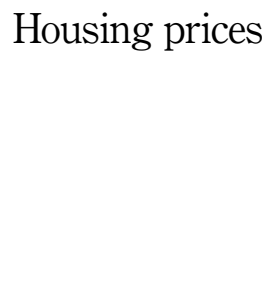

Received 13 November 2019 Revised 27 February 2020 Accepted 17 March 2020

\begin{abstract}
Purpose - This paper aims to investigate the mutual dependence between housing prices and housing credit in Estonia, a country that experienced rapid debt accumulation during the 2000s and big swings in house prices during that period.

Design/methodology/approach - The authors use Bayesian econometric methods on data spanning 2000-2015.

Findings - The estimations show the interdependence between house prices and housing credit. More importantly, negative housing credit innovations had a stronger effect on house prices than positive ones.

Originality/value - The asymmetry in the linkage between housing credit and house prices highlights important policy implications, in that if central banks increase capital buffers during good times, they can release credit conditions during hard times to alleviate the negative spillover into house prices and the real economy.
\end{abstract}

Keywords House prices, Housing credit, Credit cycle, Asymmetries, Bayesian

Paper type Research paper
JEL Classification — E32, E44, E51, G21, R21, R31

(C) Juan Carlos Cuestas and Merike Kukk. Published by Emerald Publishing Limited. This article is published under the Creative Commons Attribution (CC BY 4.0) licence. Anyone may reproduce, distribute, translate and create derivative works of this article (for both commercial \& non-commercial purposes), subject to full attribution to the original publication and authors. The full terms of this licence may be seen at: http://creativecommons.org/licences/by/4.0/legalcode.

The views expressed are those of the authors and do not necessarily represent the official views of Eesti Pank, the European Central Bank or the Eurosystem. The authors would like to thank Jana Kask, Yannick Lucotte, Martti Randveer, Nicolas Reigl, Tairi Rõõm, Mari Tamm, an anonymous reviewer and seminar participants at Eesti Pank for their useful comments. The usual disclaimer applies. Juan Carlos Cuestas acknowledges the financial support from the ECO2017-85503-R and the ECO2017-83255-C3-3-P projects from 'Agencia Estatal de Investigación' (AEI) Spain and 'Fondo Europeo de Desarrollo Regional' (FEDER). Merike Kukk acknowledges the European Union's Horizon 2020 research and innovation programme under the Marie Sklodowska-Curie grant agreement No 734712.

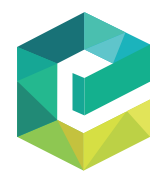

Journal of Economic Studies Emerald Publishing Limited DOI 10.1108/JES-11-2019-0519 


\section{Introduction}

The liberalisation of credit markets and easing of access to household credit since the 1970s has gradually increased the volumes of private credit in developed countries. The growth rate of private credit was noticeably high in the beginning of the 2000s. Large-scale accumulation of debt has provoked a discussion amongst academics and policymakers alike about the implications of household debt, with particular focus on the interaction between housing prices and household debt. Both policymakers and economists have sought measures to alleviate housing market fluctuations, which very often coincide with credit cycles. Several studies on industrialised countries have been published in the past 15 years on the way developments in house prices spill over into credit. However, the empirical evidence on the effect of credit on house prices is less clear. This paper investigates the interaction between house prices and housing credit in Estonia, a euro area country that experienced rapid credit accumulation and deleveraging.

The literature has explained several mechanisms that let changes in house prices affect demand for credit. The main channels, such as the wealth and collateral effect, are derived from household lifecycle models, as seen in the overview about the wealth effect by Carroll et al. (2011) and the discussion about the collateral effect by Muellbauer (2015). A rise in house prices increases the lifetime wealth of households, and the optimal consumption choice implies that households increase their consumption in response to an increase in wealth (Apergis et al., 2014). Households do not need to sell their real wealth but can instead use mortgage equity withdrawal. Hence, the wealth effect suggests that the demand for credit increases when households smooth their consumption by borrowing. The second channel, the collateral effect, means that when households are credit-constrained and cannot borrow to smooth their consumption, an increase in the value of their collateral increases their borrowing capacity.

The literature finds additional channels through which housing prices can spill over to credit, such as the asset allocation choices of households or the mechanism that works through the credit supply. Considering these asset allocation choices, Piazzesi and Schneider (2016) show that a rise in house prices increases the expected return and the demand for residential investment, implying an increase in the demand for housing credit. Finally, the mechanism may work through the credit supply, as developed in the model by Chen (2001). Higher prices improve the balance sheet of banks, and higher capitalisation makes it possible for them to issue more loans.

According to the literature, the mechanisms that carry developments in credit markets into housing markets are less clear. Muellbauer et al. (2015) pinpoint an increase in the demand for housing caused by an increase in the availability of credit if households have been borrowing-constrained.

Although transition countries in Europe experienced the largest debt accumulation and the highest rise in house prices in the 2000s before the Great Recession started and both credit issuance rates and house prices plummeted, to the best of our knowledge, the literature on the role of credit in the house price dynamics in these countries is rather thin on the ground. Estonia experienced the biggest boom and bust in the 2000s in Europe, jointly with Ireland and Spain, so we need to extend our knowledge about the linkages between credit and house prices by incorporating the turbulent periods into the study. We focus on Estonia, a small open economy that joined the European Union in 2004 and the euro area in 2011.

The contribution of the paper is threefold. First, we add empirical evidence on the linkages between credit and house prices in a deleveraging country in Europe with high debt accumulation. This knowledge helps to improve our understanding of the consequences of rapid developments in the credit market. 
Second, we investigate the asymmetries in the reaction of house prices to credit shocks. The credit cycle has been particularly pronounced, raising the question of whether similar mechanisms are at work during a boom to those seen during a bust. In this way, the findings here shed light on the need for countercyclical policy measures. To the best of our knowledge, the asymmetric response of house prices to credit has not been explored before.

Third, we use Bayesian methods to incorporate a larger set of information for a relatively short sample period. The sample limitation is an especially relevant problem for transition countries for which reliable data are available only since the 1990s, and where some data related to credit markets have been compiled for only a decade or two. The Bayesian method poses fewer restrictions than frequentist methods do on the stationarity of the data.

The remainder of the paper is organised as follows. Section 2 gives an overview of the studies on the topic, Section 3 provides the stylised facts for Estonia. Section 4 explains the methodology and the variables in the model, Section 5 the results and, finally, Section 6 summarises the study.

\section{Brief literature overview}

There is an extensive literature on the dynamics of housing markets and the determinants of housing prices in particular; see Piazzesi and Schneider (2016) for an overview. The main interest of this paper is to explore the mutual dependence between housing prices and housing credit, and therefore, we focus on empirical studies with a similar research question. The summary of the literature is given in Table A1 in the Appendix.

The evidence about the relationship between house prices and credit in advanced countries is mixed, suggesting that the period or the choice of country matters. Most studies use vector error-correction models (VECMs) for one country, and panel vector autoregressive (VAR) models for a set of countries. For example, see Brissimis and Vlassopoulos (2009) for Greece in 1993-2005, and Antonakakis and Floros (2016) for the UK.

Bidirectional causality between house prices and credit has been found by Oikarinen (2009) for Finland in 1975-2006, by Gimeno and Martínez-Carrascal (2010) for Spain in 19842009, by Anundsen and Jansen (2013) for Norway in 1986-2008 and by Turk (2015) for Sweden in 1980-2015. Overall, it appears that the effect of a house price shock to credit has been found to be stronger than the effect of a shock in the other direction. Oikarinen (2009) concludes for Finland that the interaction between housing prices and housing credit is present only after the financial deregulation process. He suggests that changes in the credit market may have affected the dynamics between housing prices and credit.

Interestingly, Fitzpatrick and McQuinn (2007) find that credit actually has a significant impact on house prices in Ireland during the period 1981-2002, and they suggest that the mechanisms prevailing in Ireland are different from the mechanisms in other European countries. Ireland experienced fast debt accumulation from 1996 until the end of the sample period, and apparently, house prices came under pressure from increasing debt volumes. However, it is not clear that this mechanism also works in other countries with rapid financial deepening. Hong Kong experienced rapid credit growth rates in the second half of the 1980s, and Gerlach and Peng (2005) investigate the relationship between credit and house prices in Hong Kong in 1982-2001. They find that the direction of causality runs from property prices to bank credit, but no impact was detected from credit to property prices. One reason could be that the incidence of deleveraging has been scarce before the 2008-2009 recession, and there have been limited possibilities to investigate a full credit cycle.

As far as we are aware, no article distinguishes between positive innovations of credit from negative ones to understand the differences between the mechanisms for credit and 
house prices over a credit cycle. A comprehensive overview by Levine (2005) confirms that financial deepening has a direct effect on the real economy, so shocks to financing affect household and firm decisions and have broad implications for the economy. Therefore, it is important to explore how credit shocks spill over into the housing market during different credit cycles, particularly for countries that have experienced rapid developments in credit markets.

The disparities in the findings about the interaction between the housing market and housing credit in different countries may emerge not only from the use of different methodologies or the variations in the sample period, but also from the dissimilarities in the developments of the housing and credit markets. The upshot of the literature review is twofold. First, there are dissimilarities in the development of housing markets in countries with fast financial deepening, and these dissimilarities deserve a closer look taken separately from high-income countries. Second, the studies that have been carried out do not cover the period of the 2008-2009 recession and its aftermath, which saw notable deleveraging. Periods of credit decrease were rare before the 2008-2009 recession, so the past decade provides new insights into the linkages between credit and the housing market and the direction of causality.

\section{Stylised facts about credit and the housing market in Estonia}

Estonia stands out among other European countries for its high rate of owner-occupancy. In Estonia, 97 per cent of the housing stock is owned by the private sector, mostly by households (Aben et al., 2013). The high ownership rate is the result of the restitution and privatisation process that followed the property reforms in 1991, prior to which dwellings were owned by the state, like land and businesses (Victorin and Lilleholt, 2001). Consequently, the proportion of owner occupation is higher than in many European countries. According to the European Union (EU) statistics on income and living conditions (EU-SILC), about 80 per cent of the population live in owner-occupied accommodation, while the EU average is 70 per cent. The high share of owner occupancy implies that house prices have an important effect on household wealth.

The quality satisfaction with the housing stock and the size of dwellings is far below the EU average [1], reflecting the high share of Soviet era apartment blocks in the overall stock of dwellings (Lamine, 2009). Construction of new dwellings increased in the beginning of the 2000 s, together with demand for new and larger dwellings. The increase in demand was supported by the rise in the purchasing power of households, as their income increased markedly in the 2000s in tandem with vigorous economic growth until 2007 (Brixiova et al., 2009). As can be seen in Panel (a) of Figure 1, house prices in Estonia experienced by far the fastest growth in Europe in the years 2000-2007, exceeding the price developments in other rapidly growing European countries like Ireland and Spain.

Another feature of Estonia is the high concentration of its banking sector following several mergers and takeovers in the 1990s, and the entry of big foreign banks. In the beginning of the 2000s, Nordic banks extended their presence in Estonia by acquiring local banks. Four foreign banks from Sweden and Denmark dominate Estonia's financial sector. The market for housing loans was underdeveloped in the 1990s, and it took off only in the beginning of the 2000s (Meriküll and Rõom, 2016). This was due to the entry at the beginning of the 2000s of foreign banks, which provided their subsidiaries with capital. Intense banking competition widened the access to credit and lowered the interest rate margins. The real interest rate of housing loans issued in euros was extremely favourable, as the nominal interest rate was determined abroad while local inflation was high. The real interest rate turned negative in 2005 (OECD, 2011).

A rapid accumulation of household debt was observed in the mid-2000s. The household sector's debt-to-income ratio shot up from 15 per cent in 2000 to 87 per cent in 
Housing prices
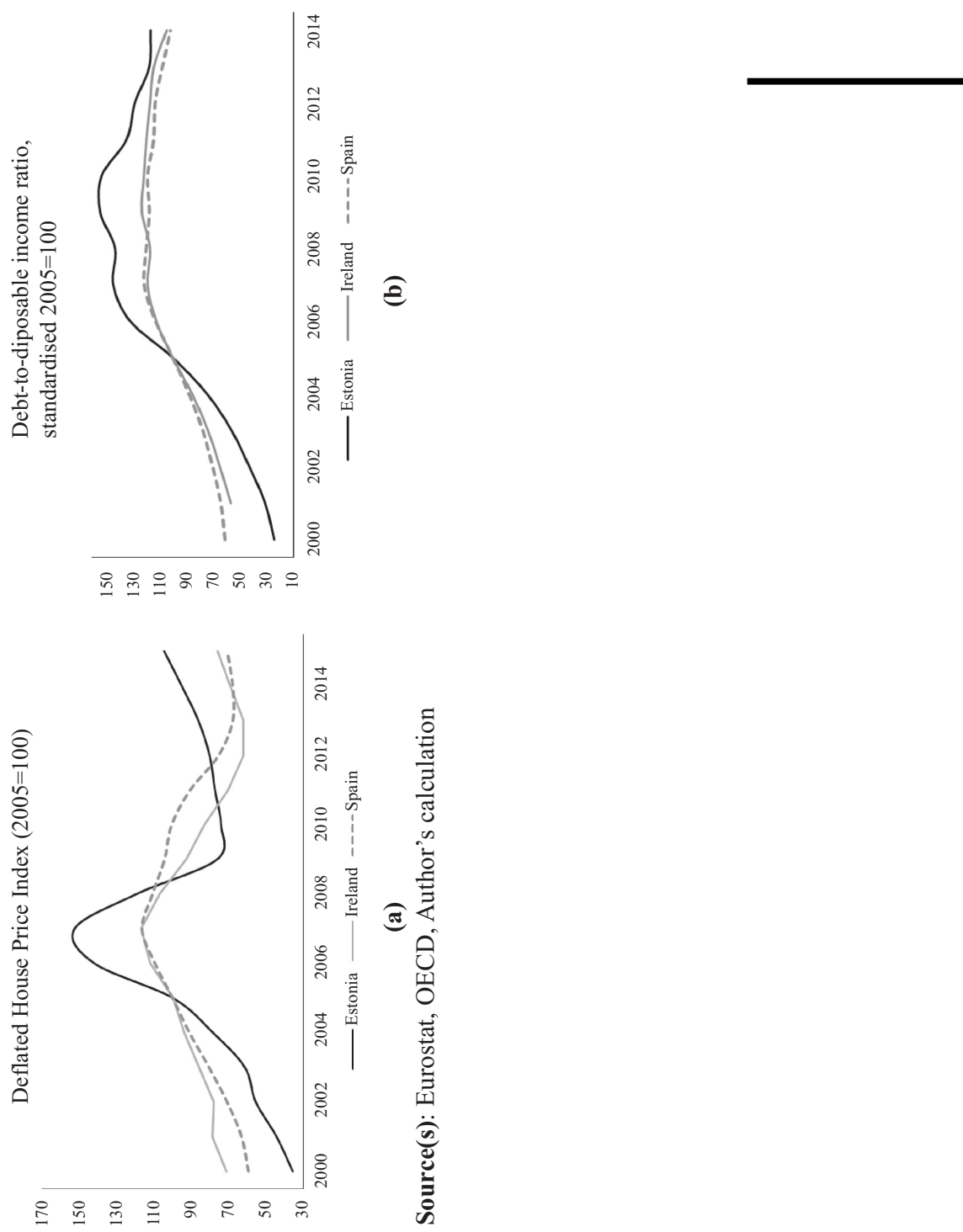

Figure 1. Comparison of house price and household debt variables 
2007, reaching almost the average level of the euro area. Panel (b) of Figure 1 shows that the debt increased at a rate above that of Ireland and Spain, which were accumulating debt at the highest rates in Western Europe. Obviously, households had been creditconstrained before the financial deepening, implying that an increase in the availability of the credit supply might have spilled over into house prices, as suggested by Muellbauer et al. (2015).

The 2008-2009 recession put matters into reverse, as real disposable income declined and income prospects weakened, credit conditions tightened and the need for credit diminished (Meriküll, 2015). The indebtedness of household sector amplified the recession by lowering household consumption (Kukk, 2016). Economies recovered, while credit volumes were still declining, and in Estonia, real housing credit volumes started to rise only in 2013. As credit continued to grow more slowly than income in 2013-2016, the indebtedness of the household sector declined.

The economic cycle has been accompanied by vigorous house price movements. The prices in 2007 were 425 per cent of the prices in 2000, but in 2009, they were at 50 per cent of their peak. Since hitting the trough in 2009, house prices have increased more in Estonia than in other European countries. The overall growth rate for 2009-2015 was almost 40 per cent, while prices in many European countries have declined.

To summarise, big swings in credit and house prices can be observed in Estonia within the 15 years, providing an excellent case for investigating the direction of causality. It is not clear whether the co-movement is induced by common cofounding factors such as economic activity, income and sentiment or whether there is a direct linkage between housing credit and housing prices.

\section{Empirical methodology}

\subsection{The econometric model}

We use structural Bayesian VAR (SBVAR) models to investigate the interaction between house prices and housing credit in Estonia [2]. The main methodology for investigating the linkages between housing prices and credit in a given country is a VECM framework that separates out long- and short-term dynamics (Gimeno and Martínez-Carrascal, 2010; Anundsen and Jansen, 2013; Gerlach and Peng, 2005). Fitzpatrick and McQuinn (2007) and Turk (2015) use the dynamic ordinary least squares (DOLS) methodology. The VECM is suitable when the data are sufficiently long, but for shorter time periods, it is challenging to identify the long-term relationship. Quarterly data are available for Estonia for 15 years from 2000Q1 to 2015Q4, which is a relatively short period.

The use of VAR models is helpful for time-series analysis when the focus is on the shortterm effects. A VAR model can be estimated by ordinary least squares, and it is written as:

$$
Y_{t}=A(L) Y_{t}+\varepsilon_{t}
$$

where $Y$ is a variables vector of $n \times 1$ dimension, $A$ is an $n \times n$ matrix of coefficients and $L$ is the lag operator, such that $A(L)=A_{0}+A_{1} L+A_{2} L^{2}+\ldots+A_{p} L^{p}$, and $\varepsilon_{t}$ is an $n \times 1$ vector containing error terms such that $\varepsilon_{i} \sim N\left(0, \sigma^{2}\right)$ for $i=1, \ldots, n$. VAR can be useful in the context of forecasting and structural models when there is a sufficiently large number of observations, as there is the risk that many degrees of freedom may be lost when the lag length is chosen. Another issue to be addressed is that the variables need to be $I(0)$ or cointegrated for any inference to be valid.

In Bayesian econometrics, each parameter of interest is treated as random with a probability distribution. In this context, the aim is to find those distributions and draw inferences from them. The Bayes theorem is the key for obtaining posterior distributions of 
the parameters, combining the prior information or prior distributions with the likelihood functions obtained from the data sample. Hence, this method uses a larger amount of information than frequentist econometrics.

In the context of Bayesian VAR analysis, it is common to use the Minnesota prior (Litterman, 1986). In our paper, we use the normal-Wishart distribution instead, which relaxes the assumption that the residual covariance matrix is known, as this could be very restrictive. In a model without exogenous variables, the variance can be expressed as:

$$
\sigma_{a_{i j}}^{2}=\left(\frac{1}{\sigma_{j}^{2}}\right)\left(\frac{\lambda_{1}}{l^{\lambda_{3}}}\right)
$$

where $l$ is the lag for the coefficient, $\lambda_{1}$ is the own lag variance, also known as overall tightness, and $\lambda_{3}$ is a scaling constant which controls the speed of convergence to 0 for the coefficients of lags greater than 1 . As is common in the literature we have set $\lambda_{1}=0.2$ and $\lambda_{3}=1$. In addition, given that the variables considered here are mostly I(1), we have set the autoregressive parameter to be equal to 1 [3] Applying the Bayesian VAR, we then obtain posterior impulse response functions using SBVAR and Cholesky factorisation (Sims, 1980). The ordering of the variables and the shocks are explained in more detail in Subsection 5.1.

The models identified can be written as:

$$
\gamma y_{t}=B(L) y_{t}+\varepsilon_{t}
$$

where $\gamma$ is the matrix of contemporaneous restrictions, and $B$ is a matrix of coefficients for the lagged variables.

\subsection{The variables in the baseline model}

The main variables in the model are the standard determinants of house prices and credit in the literature. As mentioned before, the data sample spans 2000Q1-2015Q4. Table A2 in the Appendix gives the list of variables and the different sources used to obtain the variables. The house price index is a proxy of the price of dwellings, which covers new and existing apartments and houses. The geometric mean of the square metre prices of all transactions with dwellings is used, with extreme prices excluded.

To measure household credit, we use new loans originated from housing purchase, like Fitzpatrick and McQuinn (2007) do for Ireland. Several papers use the balance of total private credit (Hofmann, 2004; Gerlach and Peng, 2005) or household credit including consumer credit (Turk, 2015; Anundsen and Jansen, 2013). The balance of credit depends on the amounts repaid or the loan amortisation rate $\delta$ and on the amounts of new loans issued $N_{t}$ during the period so that the credit stock $C_{t}$ follows $C_{t}=(1-\delta) C_{t-1}+N_{t}$. As the credit stock is fairly persistent, the repayments are usually fixed by loan contracts, and therefore, the volume of new loans granted is a more precise measure for indicating the outcome of the demand for credit and the supply of it. The volume of new loans is expressed in euros in real terms, deflated by the harmonised index of consumer prices (HICP).

Real labour income (compensation to employees) is used as a proxy for disposable income, which is not available quarterly. A similar approach is used by Gimeno and MartínezCarrascal (2010), who argue that labour income is more tightly related to credit volumes because banks use wage income as the main measure for assessing the financial credibility of households when they apply for mortgages.

The nominal interest rate instead of real interest rate is used by Gimeno and MartínezCarrascal (2010) for Spain as a proxy for the price of loans. Their argument is that the amount of credit issued by banks is restricted by the debt service burden, which is determined by the nominal interest rate. The same argument is used by Kiss et al. (2006) when they include 
inflation alongside the real interest rate in the model explaining credit in the euro area and Central and Eastern European countries. They estimate a similar coefficient for the inflation and real interest rates, and they argue that the results show that the nominal interest rate is the one that matters for credit. Turk (2015) uses nominal mortgage rates when exploring the short-run dynamics between house prices and credit in Sweden.

For the supply side, we capture the changes in the stock of housing by using new dwellings completed, as in Gerlach and Peng (2005) and Fitzpatrick and McQuinn (2007). Housing stock is used in Anundsen and Jansen (2013) and Turk (2015). However, housing stock is a slow-moving variable, and in an economy with a high ownership rate like Estonia's, the stock does not reflect the response of the supply to the demand for housing.

According to the households lifecycle model, housing credit demand depends on expectations, so when households expect their income to increase, they borrow to shift future consumption into the current period (Jappelli and Pistaferri, 2010). In this vein, Anundsen and Jansen (2013) find that expectations have a strong impact on house prices [4]. The sentiment and expectations of households are captured by the consumer confidence index. Following this approach, we also incorporate the consumer confidence index in our analysis.

In addition, the literature on international finance shows that capital inflows may boost the credit supply, and this can also affect house prices (Tillman, 2013; Cuestas and Staehr, 2017). We use different measures of capital flows such as the change in net financial liabilities, as in Cuestas and Staehr (2017), the current account and the financial account, leaving the latter as the variable that is a proxy for capital inflows [5].

To summarise, we estimate the posterior impulse response functions using a SBVAR for shocks to real labour income, consumer confidence, new dwellings, house prices, new loans or credit turnover and the nominal interest rate and capital inflows. The variables have been transformed into natural logs, except the consumer confidence index and the interest rate. The dynamics of the two main variables in focus, the log of the real house price index and the $\log$ of real credit turnover, are given in Figure 2. We can clearly see the co-movement of the variables, with the growth rates substantially higher for the credit turnover than for the house price index.

\section{Estimations}

\subsection{Baseline estimations}

In Figure 3, we present the impulse response functions for the SBVAR, using Cholesky factorisation, for the two main variables, which are the house price index and new housing

\section{Figure 2.}

The dynamics of the main two variables in the model, log of the real house price index and log of the turnover of housing loans in real terms

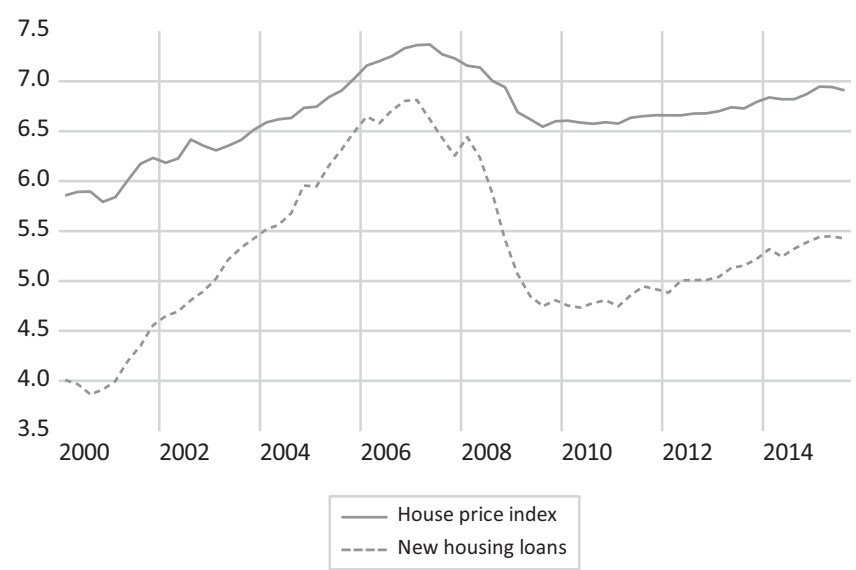


Housing prices
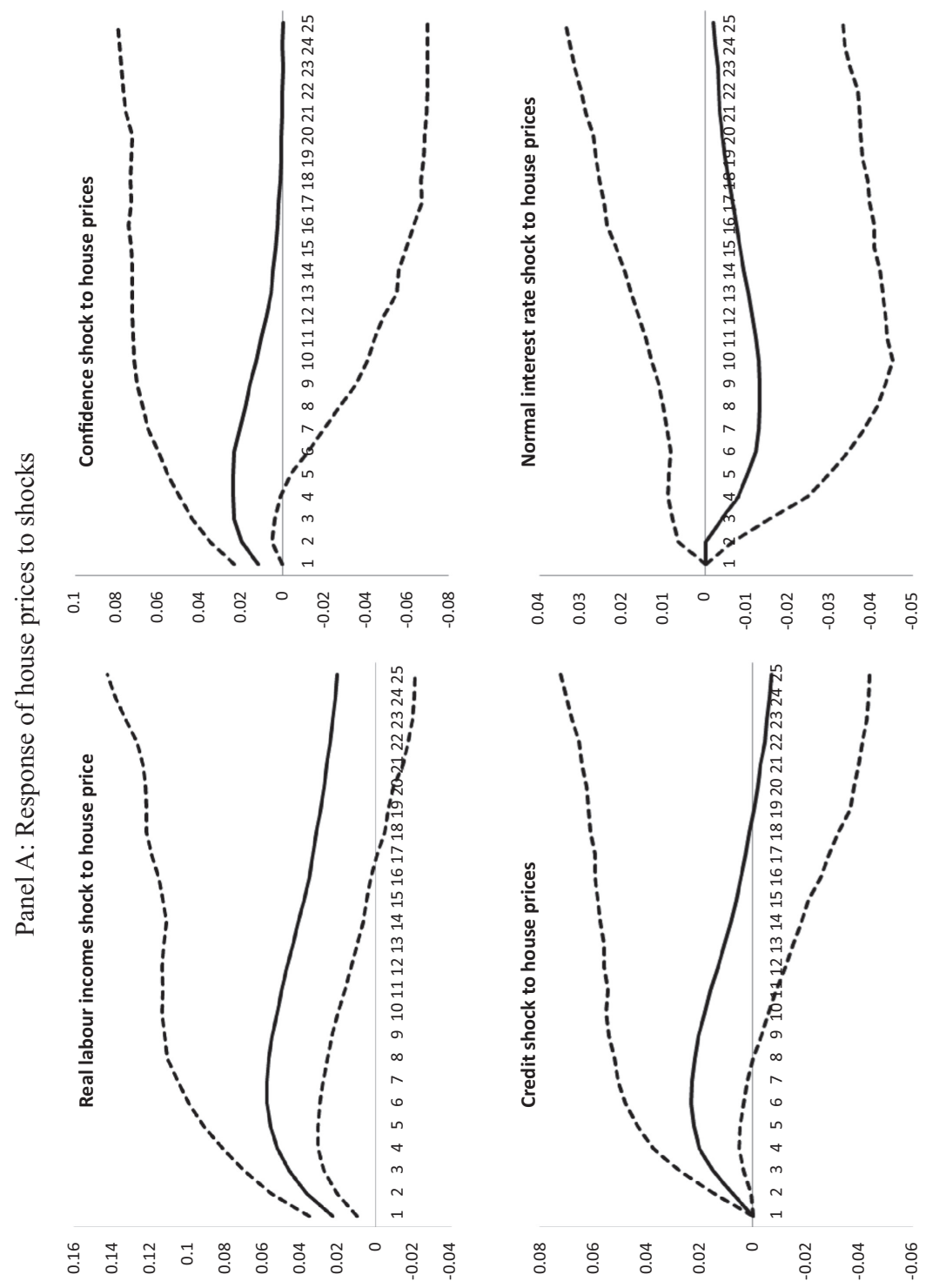

Figure 3. 
JES

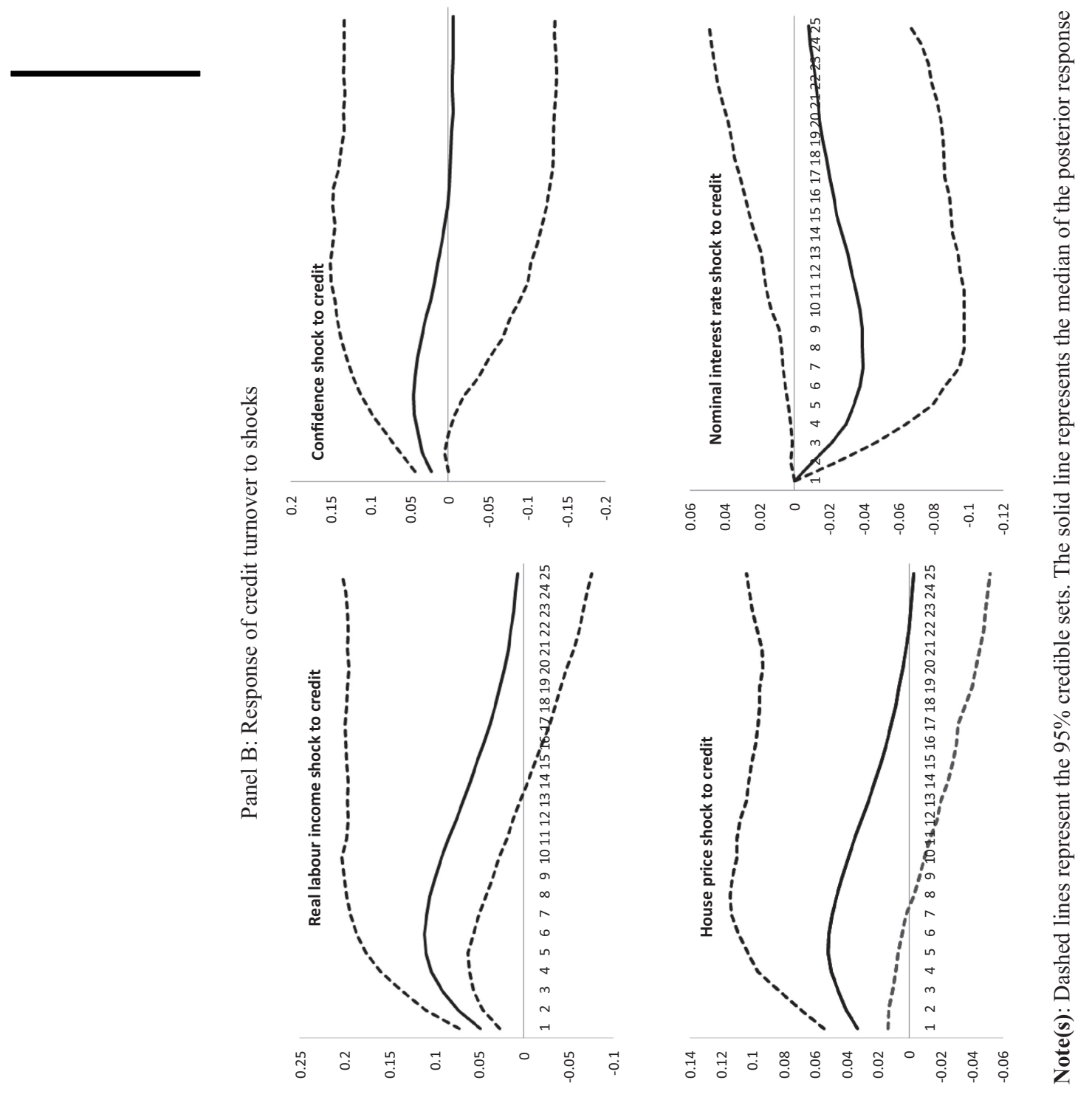

Figure 3. 
loans. Four lags are used in the VAR with a constant term. The variables have been seasonally adjusted using the X-12 procedure when seasonality was present.

The ordering of the variables matters for identifying the shocks. Here, we have used a similar shock identification to that in Hofmann (2004), and Oikarinen (2009), considering real labour income, the confidence index, new dwellings, the house price index, new loans, nominal interest rates and capital inflows from the financial account. We do not report the impulse response functions for the effect of shocks to new dwellings and the proxies for capital flows, as the results do not show any significant shifts in the posterior distributions. However, we keep these variables in the model to ensure that all theoretically important variables are considered.

The precise ordering of the variables implies that income does not respond contemporaneously to shocks to the rest of the variables, but the other variables would react in the present period to an income shock. We expect house prices to react to shocks to labour income, confidence and the supply of dwellings in the same period, but the response to shocks to new loans, the interest rate and capital inflows appears only in the following periods. New loans do not react contemporaneously to innovations in interest rates and capital inflows. This means house prices are stickier than new loans, as also suggested in Oikarinen (2009).

Figure 3 provides the impulse response posterior distributions for the spillover of different shocks to house prices and credit. The house price index is affected by shocks to real labour income, confidence and credit turnover, but we do not find a clear response of house prices to shocks to the nominal interest rate. The sign of the effect is the one expected in all cases. The impulse response functions show that shocks to real labour income have a long-term effect on house prices, as the positive shock to real labour income affects house prices positively after 25 quarters, though this conclusion is tentative because of the increase in the credible sets of the posterior distributions. The shocks to confidence and credit turnover clearly have a shortterm effect on house prices, as the peak of the median of the posterior distribution for credit turnover comes six-quarters after the shock and the posterior median moves slowly towards zero.

These findings are consistent with a policy study discussing the determinants of house prices in Estonia. Brixiova et al. (2009) estimate the error correction model using quarterly data from 1997:Q3 to 2008:Q1. They focus on the long-term equation and find that demand factors captured by real disposable income and the real mortgage rate played a major part in the rise of house prices, while the supply factor measured by housing stock per person is not statistically significant in any of the models. Brixiova et al. (2009) neither tested the relationship between house prices and housing credit nor included consumer confidence in their model.

The lower panel of Figure 3 relates to credit turnover and shows that shocks to real labour income, confidence and house prices affect credit turnover, while a shock to the nominal interest rate does not shift the posterior distribution enough to indicate that it has had a distinct effect. The effect of all the shocks to credit turnover is temporary, and the shock to real income is the slowest to die out. The effect of the house price shock on credit turnover dies out in approximately 4.5 years according to the median response of the posterior distribution. For comparison, the response of house prices to a credit shock has a somewhat smaller magnitude and dies out faster, in 3.5 years.

To test for robustness, we proceed as follows [6]. First, as the nominal interest rate does not seem to have any impact on the other variables, we have replaced the nominal interest rate with the real interest rate, as several studies use the real interest rate in the model (Gerlach and Peng, 2005; Oikarinen, 2009; Anundsen and Jansen, 2013). The real interest rate is calculated by deducting inflation from the nominal interest rate, assuming rational expectations. However, shocks to this variable showed an even smaller reaction in credit and house prices, and the results have been omitted. 
In addition, we replaced labour income with gross domestic product (GDP), which has been used by some studies to capture general economic activity (Hofmann, 2004; Gerlach and Peng, 2005; Oikarinen, 2009). The results are similar, but the effect from GDP to house prices is less clear than the effect from real labour income to house prices.

We carried out estimations with different ordering of the shocks to see how sensitive the results are to the ordering of the variables. The estimations are qualitatively the same in any set of ordering. Moreover, we have run the model without the variables for dwellings and capital flow, as the shocks to these variables did not show any response on the other variables [7]. Finally, we have estimated the reduced model using VAR/VECM, and the results are quantitatively similar, suggesting that the results are robust to different model specifications.

Our results confirm the interdependence between house prices and credit as (1) house prices react to credit turnover innovations to and (2) housing credit reacts to house price shocks. The effect from house prices to housing credit is slightly stronger than the effect the other way around. One limitation of the estimations is that the models used here are linear and assume symmetric responses where the magnitude of the response is the same over a credit cycle.

\subsection{Asymmetric analysis of housing credit}

We are interested in whether the effect of positive innovations in credit turnover on house prices is different from the effect of negative ones. It is sensible to think that the depressing effect on housing prices of a credit cut may be different in magnitude to the effect of credit expansion. For instance, in good times, when income expectations, and hence credit demand, are high, the amounts of credit issued are still limited by current income levels, inducing an upper limit for credit growth, and meaning credit turnover can have only a limited impact on house prices. However, during bad times, there is no lower limit for credit, and the full effect of a credit decline can be transmitted into house prices. There is a growing literature finding asymmetric reactions in the economy to monetary and fiscal policy shocks, where negative shocks exhibit a stronger effect on the economy than positive shocks do (Auerbach and Gorodnichenko, 2012; Caglayan et al., 2017; Florio, 2004). Similarly, it is reasonable to assume that house prices do not exhibit a symmetric response to the shocks in the credit market.

To isolate periods of credit accumulation and de-accumulation, the credit turnover variable has been split into two variables, which are partial cumulative sums, so that:

$$
\begin{aligned}
& \text { turnover }_{t}^{+}=\sum_{j=1}^{T} \max \left(\Delta \text { turnover }_{j}, 0\right) \\
& \text { turnover }_{t}^{-}=\sum_{j=1}^{T} \min \left(\Delta \text { turnover }_{j}, 0\right)
\end{aligned}
$$

The same approach has been used in the literature about the effect of oil price changes on the real economy. We are interested in the asymmetric effect of credit on house prices, and therefore, we split the credit turnover in the similar way as oil price increases and decreases have been considered to be separate variables in the model by Cunado and De Gracia (2005) and Cuestas and Ordóñez (2018). Hence, we include two variables in the model, one for positive changes in credit turnover and one for negative changes in credit turnover. Impulse response functions show how the other variables in the model respond to a one standard deviation credit turnover innovation during the period of increasing credit turnover, which can be interpreted as a positive credit shock. One standard deviation credit turnover innovation during the period of decreasing credit turnover refers to a negative credit shock. 
In the upper panel of Figure 4, we show the reaction of house prices to positive and negative credit innovations, and in the lower panel, the effect of house price shocks on credit when credit turnover is falling and when it is increasing. Note that the way the graph is drawn implies that both variables move in the same direction, so a positive evolution of the posterior distributions for the period of negative credit turnover shows that house prices also move downward.

The first feature to notice is that the patterns for the positive and negative innovations seem to be similar. However, we observe differences in the magnitudes of the credible sets of the posterior responses. We detect a positive response by house prices to a positive credit innovation, as the median of posterior distribution is hump-shaped, but the credible sets of the posterior distributions cross the zero line from the beginning, making it difficult to draw any strong conclusions. We do see though that a negative credit innovation reduces house prices, as the median of the posterior mean is highest four-quarters after a shock and the effect disappears in three years. The results suggest that the apparent causation we found in the previous subsection from credit to house prices occurs more clearly for negative credit innovations. This implies that the effect of increasing new housing loans on housing prices is somewhat weaker.

The lower panel in Figure 4 illustrates the spillover of house price shocks. We also notice an asymmetric response, as it is observed that a house price shocks seems to shift the posterior distribution of the response to credit when credit turnover is increasing, whereas the shift is not that clear when the amount of new lending is falling. The results indicate that the credit turnover is affected stronger by house prices in the period of credit growth than in the bust period. This means that banks are more willing to release credit in good times than in bad times.

As a result, the interdependence between house prices and credit is much more complex when the full credit cycle is taken into account, both growth and bust periods. We detect a stronger response from credit turnover to house prices in the period when credit volumes are decreasing, while there is a stronger reaction from house prices to credit turnover when the credit turnover is increasing.

\subsection{Discussion of the results}

The findings for Estonia are similar to the results for Spain and Hong Kong where we can also find similarities in the economic development. In Spain, EMU membership in 1986 increased income expectations, but at the same time, decreased financing costs. Gimeno and MartínezCarrascal (2010) show that Spain experienced extraordinarily high levels of debt accumulation from the 1990s to the mid-2000s. Spain experienced house price rises from the 1980s onwards, except in 1992-1996 when stagnation occurred. Gimeno and MartínezCarrascal (2010) reveal that the causality between house prices and housing credit in Spain in 1980-2009 goes in both directions, but the effect from house prices to credit is stronger than that from credit to house prices. Estonia joined the EU in 2004 and then experienced similar developments to those in Spain, and we find a similar two-way relationship between housing credit and housing prices. However, the sample period for Spain does not include periods of credit decline; hence, the findings about the effect of credit to house prices rely only on the credit growth period.

Gerlach and Peng (2005) investigate house prices and credit in Hong Kong using data for 1982-2001. The economic development in Hong Kong in the second half of the 1970s and the beginning of the 1980s can be compared to the situation in Estonia in the 2000s, with extensive capital flows, negative real interest rates and high demand for credit. Hong Kong experienced big swings in real estate prices in the 1980s, following rapid growth in bank credit in the second half of the 1970s. Gerlach and Peng (2005) find that shocks to house prices spill over into credit but do not find any impact from credit on house prices. They conclude that excessive bank lending was not the main cause of the boom and bust cycles of the 
JES
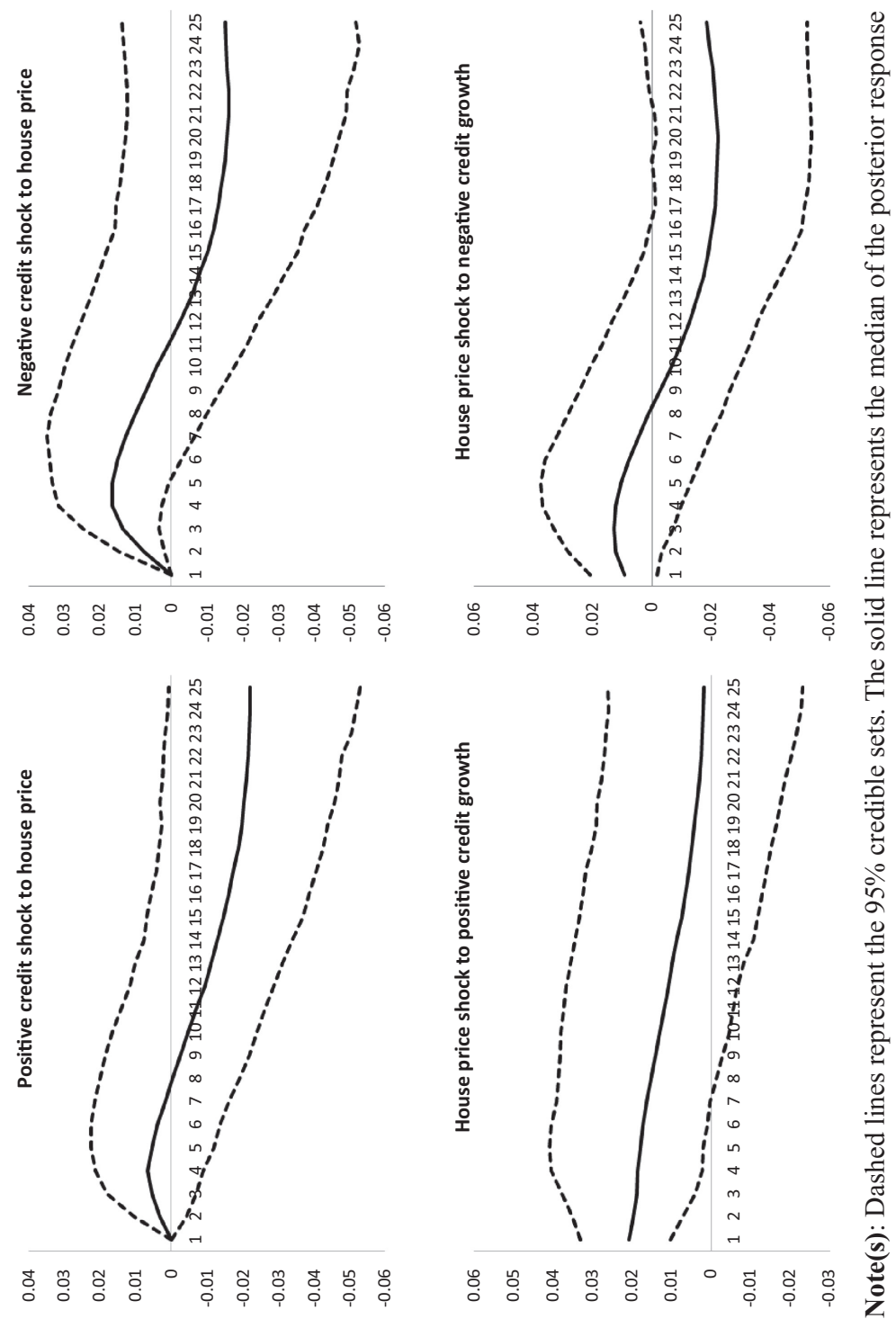

Figure 4.

Impulse response

functions Estonia,

asymmetric effect 
property market in Hong Kong, and that there must have been other factors that led to the swings in property prices. Similarly to the study on Ireland, the sample period for Hong Kong includes only the credit growth period, and the findings cannot be extended to the deleveraging period. We conclude the same only for the credit growth period in Estonia; there must have been other factors that led to the simultaneous upward movement of housing credit and housing prices.

Although fast developments in credit and housing markets have also been observed for Ireland, the results by Fitzpatrick and McQuinn (2007) for Ireland in 1980-2002 are less comparable to our findings. They find that there is a stronger effect from housing credit to house prices than the other way around and posit that increased immigration and stickiness of the housing supply in Ireland during this period explain the result. Ireland experienced rapid economic growth in the 1990s, converging with the average Western European levels of income, and the boom continued in the 2000s. It is noticeable that both the housing market and the mortgage market experienced an upsurge after 1996 in Ireland, but there were no housing market not mortgage busts during the sample period; hence, the findings apply only to the growth periods of both house prices and credit.

The studies on Spain and Hong Kong include sample periods with declines in house prices, but none of the studies observes the periods when the housing credit is decreasing, and therefore, asymmetries in the relation to credit cycles cannot be detected. In Estonia, the deleveraging was particularly pronounced after the 2008-2009 recession, the debt-toincome ratio declined by 31 per cent in 2009-2013. Hence, we can provide new insights into the relationship between credit and house prices during a credit crunch. Using data from before and after the recession, we can distinguish between positive and negative innovations in housing credit volumes, and we are able to detect asymmetries. Our estimations show that there is a clear asymmetric effect of increases and decreases in credit turnover on house prices, meaning that the effect of house price shocks to credit is stronger during periods of credit de-accumulation than during periods of credit accumulation.

Our results contribute to the literature by pinpointing the asymmetries in the spillover of the shocks. The findings indicate the need for policy measures to be set up countercyclically, with different requirements for capital buffers in times of credit accumulation and deaccumulation for example. The requirement to increase capital during good times could be released during bad times to avoid a credit crunch occurring.

\section{Conclusions}

In this paper, we have analysed the interdependence between house prices and housing credit in Estonia. The contribution of the paper is twofold, as it investigates Estonia, which experienced extraordinarily high levels of debt accumulation in the 2000s and deleveraging after the 2008-2009 recession, and it distinguishes between credit cycle periods when new credit volumes are increasing or decreasing. We expect an asymmetric response from house prices to shocks to housing credit, as credit conditions set an upper limit, given by income, for new loans even during credit expansion periods, while there is no lower limit during credit contraction periods.

We use quarterly data from 2000-2015 and SBAR to obtain the impulse response functions of shocks to real labour income, consumer confidence, new dwellings, real house price index, nominal interest rate on new loans and capital inflows. Like other studies, we find interdependence between house prices and housing credit, with the effect from house prices to credit stronger than that from credit to house prices. The most important novel finding of the paper is that a negative innovation to housing credit suppresses house prices, while the upward pressure on house prices from new credit is weaker when credit turnover is increasing. 
The results highlight the existence of asymmetries in the response of house prices to credit shocks. There is a growing literature that proposes the existence of asymmetric responses to fiscal policy or monetary policy shocks. The main consensus is that the effect of policy shocks on GDP is stronger during recessions than during booms, indicating the importance of countercyclical policy measures. The results in this paper indicate that a similar asymmetric effect applies to the relationship between credit and house prices.

This is an important contribution to the literature, as to the best of our knowledge, there are no papers investigating the asymmetric mechanisms with respect to credit. The finding that house prices are more sensitive to negative credit innovations implies that when designing the appropriate policy measures, policymakers might need to pay more attention to credit crunch periods when credit shocks exhibit a stronger amplification mechanism. As it is very difficult to develop countercyclical measures for depression periods alone, a solution could be that the measures that have been passed during credit boom periods can be released or loosened during depressions.

\section{Notes}

1. Approximately 80 per cent of the population is satisfied with the dwelling stock in Estonia, while the EU average is 90 per cent. In Estonia, the average size of a dwelling is $67 \mathrm{~m}^{2}$, and in the EU, it is $96 \mathrm{~m}^{2}$ (EU-SILC ad hoc module from 2012).

2. The Bayesian method has also been used in the context of housing prices in Gupta and Das (2010).

3. We have estimated the models with different values for the hyperparameters, and we find that the posterior of the response function to a shock does not change qualitatively. In some cases, the credible sets become wider or narrower, but because these are only informative for the shape of the posterior distribution, and for not statistical significance, we can conclude that the results are robust to different values of hyperparameters for the priors. We gratefully acknowledge an anonymous referee for pointing this out.

4. Anundsen and Jansen (2013) use households' expectations about future development in their personal economy and the state of the macroeconomy. They interpret the measure as a consumer confidence indicator.

5. See Cuestas (2017) for the case of Spain.

6. The additional estimations are not reported but are available from the authors upon request.

7. We have also investigated two sub-periods separately, taking the period until the 2008-2009 recession and the period since the recession, but this meant the periods became too small.

\section{References}

Aben, M., Kukk, M. and Staehr, K. (2013), "Housing equity withdrawal and consumption dynamics in Estonia 2002-2011”, Research in Economics and Business: Central and Eastern Europe, Vol. 4 No. 1, pp. 19-40.

Agnello, L. and Schuknecht, L. (2011), "Booms and busts in housing markets: determinants and implications", Journal of Housing Economics, Vol. 20 No. 3, pp. 171-190.

Antonakakis, N. and Floros, C. (2016), "Dynamic interdependencies among the housing market, stock market, policy uncertainty and the macroeconomy in the United Kingdom”, International Review of Financial Analysis, Vol. 44, pp. 111-122.

Anundsen, A.K. and Jansen, E.S. (2013), "Self-reinforcing effects between housing prices and credit", Journal of Housing Economics, Vol. 22 No. 3, pp. 192-212.

Apergis, N., Simo-Kengne, B. and Gupta, R. (2014), "The long-run relationship between consumption, house prices and stock prices in South Africa: evidence from provincial-level data", Journal of Real Estate Literature, Vol. 22 No. 1, pp. 83-99. 
Auerbach, A.J. and Gorodnichenko, Y. (2012), "Measuring the output responses to fiscal policy", American Economic Journal: Economic Policy, Vol. 4 No. 2, pp. 1-27.

Brissimis, S.N. and Vlassopoulos, T. (2009), "The interaction between mortgage financing and housing prices in Greece”, The Journal of Real Estate Finance and Economics, Vol. 39 No. 2, pp. 146-164.

Brixiova, Z., Vartia, L. and Wörgötter, A. (2009), "Capital inflows, household debt and the boom bust cycle in Estonia", William Davidson Institute, Working Paper No. 965.

Caglayan, M., Kandemir, O. and Mouratidis, K. (2017), "Financial depth and the asymmetric impact of monetary policy", Oxford Bulletin of Economics and Statistics, Vol. 79, pp. 1195-1218.

Carroll, C.D., Otsuka, M. and Slacalek, J. (2011), "How large are housing and financial wealth effects? A new approach”, Journal of Money, Credit, and Banking, Vol. 43 No. 1, pp. 55-79.

Chen, N.K. (2001), "Bank net worth, asset prices and economic activity", Journal of Monetary Economics, Vol. 48 No. 2, pp. 415-436.

Cuestas, J.C. and Ordóñez, J. (2018), "Oil prices and unemployment in the UK before and after the crisis: a Bayesian VAR approach. A note”, Physica A, Vol. 510, pp. 200-207.

Cuestas, J.C. and Staehr, K. (2017), "The Great leveraging in the European crisis countries: domestic credit and net foreign liabilities", Journal of Economics Studies, Vol. 44, pp. 895-910.

Cuestas, J.C. (2017), "House prices and capital flows in Spain during the boom: evidence for a coiontegrated VAR and a structural Bayesian VAR", Journal of Housing Economics, Vol. 37, pp. 22-28.

Cunado, J. and De Gracia, F.P. (2005), "Oil prices, economic activity and inflation: evidence for some Asian countries", The Quarterly Review of Economics and Finance, Vol. 45 No. 1, pp. 65-83.

Fitzpatrick, T. and McQuinn, K. (2007), "House prices and mortgage credit: empirical evidence for Ireland”, The Manchester School, Vol. 75 No. 1, pp. 82-103.

Florio, A. (2004), "The asymmetric effects of monetary policy", Journal of Economic Surveys, Vol. 18 No. 3, pp. 409-426.

Gerlach, S. and Peng, W. (2005), "Bank lending and property prices in Hong Kong”, Journal of Banking and Finance, Vol. 29 No. 2, pp. 461-481.

Gimeno, R. and Martínez-Carrascal, C. (2010), "The relationship between house prices and house purchase loans: the Spanish case", Journal of Banking and Finance, Vol. 34 No. 8, pp. 1849-1855.

Gupta, R. and Das, S. (2010), "Predicting downturns in the US housing market: a Bayesian approach", The Journal of Real Estate Finance and Economics, Vol. 41 No. 3, pp. 294-319.

Hofmann, B. (2004), "The determinants of bank credit in industrialized countries: do property prices matter?", International Finance, Vol. 7, pp. 203-234.

Jappelli, T. and Pistaferri, L. (2010), “The consumption response to income changes”, National Bureau of Economic Research, No. w15739.

Kiss, G., Nagy, M. and Vonnák, B. (2006), "Credit growth in Central and Eastern Europe: convergence or boom? Magyar Nemzeti Bank (Central Bank of Hungary), Working Paper No. 2006/10.

Kukk, M. (2016), "How did household indebtedness hamper consumption during the recession? Evidence from micro data", Journal of Comparative Economics, Vol. 44 No. 3, pp. 764-786.

Lamine, B. (2009), "Estonia: analysis of a housing boom”, ECFIN Country Focus, Vol. 4 No. 7.

Levine, R. (2005), "Finance and growth: theory and evidence", in Handbook of Economic Growth, Vol. 1A, Aghion, P. and Durlauf, S.N. (Eds), North-Holland, Amsterdam, pp. 865-934.

Litterman, R. (1986), "Forecasting with Bayesian vector autoregressions - five years of experience", Journal of Business and Economic Statistics, Vol. 2 No. 4, pp. 497-498.

Meriküll, J. and Rõõm, T. (2016), "The assets, liabilities and wealth of Estonian households: results of the household finance and consumption survey”, Eesti Pank Occasional Paper series, No. 1/2016. 
Meriküll, J. (2015), "Household borrowing during a creditless recovery", Emerging Markets Finance and Trade, Vol. 51 No. 5, pp. 1051-1068.

Muellbauer, J., St-Amant, P. and Williams, D. (2015), "Credit conditions and consumption, house prices and debt: what makes canada different?", Bank of Canada, Working Paper No. 15-40.

OECD (2011), Estonia Review of the Financial System, The Committee on Financial Markets, Paris, October 2011, available at: http:/www.oecd.org/finance/financial-markets/49497930.pdf.

Oikarinen, E. (2009), "Interaction between housing prices and household borrowing: the Finnish case", Journal of Banking and Finance, Vol. 33 No. 4, pp. 747-756.

Piazzesi, M. and Schneider, M. (2016), "Housing and macroeconomics", in Handbook of Macroeconomics.

Sims, C.A. (1980), "Macroeconomics and reality", Econometrica, Vol. 48 No. 1, pp. 1-48.

Tillmann, P. (2013), "Capital inflows and asset prices: evidence from emerging Asia”, Journal of Banking and Finance, Vol. 37 No. 3, pp. 717-729.

Turk, R. (2015), "Housing price and household debt interactions in Sweden”, IMF Working Paper No. 276.

Victorin, A. and Lilleholt, K. (2001), "Legal framework of user-owned dwellings in the Baltic countries", TemaNord 2001, Vol. 544, Nordic Council of Ministers, Copenhagen.

\section{Appendix}

\begin{tabular}{|c|c|c|c|c|}
\hline Authors & Country & Period & Method & Results \\
\hline Hofmann (2004) & $\begin{array}{l}16 \text { industrialised } \\
\text { countries }\end{array}$ & $\begin{array}{l}1985- \\
2001\end{array}$ & VAR & $\begin{array}{l}\text { Property prices } \rightarrow \text { private credit } \\
\text { (including household and } \\
\text { corporate credit) } \\
\text { No evidence for private } \\
\text { credit } \rightarrow \text { property prices }\end{array}$ \\
\hline $\begin{array}{l}\text { Agnello and } \\
\text { Schuknecht (2011) }\end{array}$ & $\begin{array}{l}18 \text { industrialised } \\
\text { countries }\end{array}$ & $\begin{array}{l}1980- \\
2007\end{array}$ & $\begin{array}{l}\text { Multinominal } \\
\text { probit model }\end{array}$ & $\begin{array}{l}\text { Private credit } \rightarrow \text { house prices } \\
\text { The effect is stronger during } \\
\text { house price busts }\end{array}$ \\
\hline $\begin{array}{l}\text { Gerlach and Peng } \\
\text { (2005) }\end{array}$ & Hong Kong & $\begin{array}{l}1982- \\
2002\end{array}$ & VECM & $\begin{array}{l}\text { Property prices } \rightarrow \text { private credit } \\
\text { (households and corporates) } \\
\text { No evidence for private } \\
\text { credit } \rightarrow \text { property prices }\end{array}$ \\
\hline $\begin{array}{l}\text { Fitzpatrick and } \\
\text { McQuinn (2007) }\end{array}$ & Ireland & $\begin{array}{l}1981- \\
2002\end{array}$ & VECM & $\begin{array}{l}\text { New housing loans } \rightarrow \text { house prices } \\
\text { No evidence for house } \\
\text { prices } \rightarrow \text { credit }\end{array}$ \\
\hline $\begin{array}{l}\text { Brissimis and } \\
\text { Vlassopoulos (2009) }\end{array}$ & Greece & $\begin{array}{l}1993- \\
2005\end{array}$ & VECM & $\begin{array}{l}\text { House prices } \rightarrow \text { housing loans } \\
\text { No evidence that housing loans } \\
\text { affect house prices }\end{array}$ \\
\hline Oikarinen (2009) & Finland & $\begin{array}{l}1975- \\
2006\end{array}$ & VECM & $\begin{array}{l}\text { House prices } \rightarrow \text { housing credit } \\
\text { Housing credit } \rightarrow \text { house prices }\end{array}$ \\
\hline $\begin{array}{l}\text { Gimeno and } \\
\text { Martinez-Carrascal } \\
\text { (2010) }\end{array}$ & Spain & $\begin{array}{l}1984- \\
2009\end{array}$ & VECM & $\begin{array}{l}\text { House prices } \rightarrow \text { housing credit } \\
\text { Housing credit } \rightarrow \text { house prices }\end{array}$ \\
\hline $\begin{array}{l}\text { Anundsen and } \\
\text { Jansen (2013) }\end{array}$ & Norway & $\begin{array}{l}1986- \\
2008\end{array}$ & SVECM & $\begin{array}{l}\text { House prices } \rightarrow \text { household credit } \\
\text { (housing and consumer credit) } \\
\text { Household credit } \rightarrow \text { house prices }\end{array}$ \\
\hline Turk (2015) & Sweden & $\begin{array}{l}1980- \\
2015\end{array}$ & VECM & $\begin{array}{l}\text { House prices } \rightarrow \text { household credit } \\
\text { (housing and consumer credit) } \\
\text { Household credit } \rightarrow \text { house prices }\end{array}$ \\
\hline
\end{tabular}

Table A1.

Summary of the literature 
Description

$\mathrm{HICP}$

Log of real house price index deflated by the HICP

Log of new housing loans in real terms, deflated by the HICP, seasonally adjusted

Log of labour income deflated by HICP

Nominal interest rate for housing loans divided by 100

Real interest rate for housing loans deflated by HICP and divided by 100 , seasonally adjusted

Log of new dwellings completed, seasonally adjusted

Consumer confidence indicator

Capital inflows in real terms (change in net foreign liabilities,

financial account and current account), seasonally adjusted
Source

\section{Housing prices}

Eurostat

Bank of Estonia (computed from the data

from the Land Board)

Bank of Estonia

Eurostat

Bank of Estonia

Bank of Estonia

Statistics Estonia

Eurostat

Eurostat
Table A2.

Variable definitions and sources

\section{Corresponding author}

Juan Carlos Cuestas can be contacted at: cuestas@uji.es

For instructions on how to order reprints of this article, please visit our website: 